\title{
Grundtvig i Kina
}

\section{Af Stig Thøgersen}

Grundtvigs tanker og virke blev præsenteret for et kinesisk publikum i begyndelsen af dette århundrede som led i Kinas første store åbning mod Vesten. Fra 1890erne, hvor det sidste kejserdynasti (manchuernes Qing dynasti, 1644-1911) indså behovet for reformer, til 1937, hvor krigen mod den japanske besættelsesmagt gjorde simpel overlevelse til det altoverskyggende tema, foregik der en livlig debat $\mathrm{i}$ Kina om de store nationale og sociale spørgsmål: hvordan kunne Kina igen blive rigt, stærkt og respekteret af verdens stormagter, og hvordan kunne den kinesiske befolkning løftes ud af fattigdom og uvidenhed. Udenlandske tankeretninger og modeller spillede en afgørende rolle i denne debat, som ikke kun var teoretisk, men efterhånden også fandt praktiske udtryk $\mathrm{i}$ konkrete sociale eksperimenter, hvor hele amter blev omformet efter reformatorernes ideer.

I den sammenhæng spillede Grundtvig, de danske højskoler og andelsbevægelsen en vigtig men overset rolle, som er emnet for denne artikel. Jeg vil ikke komme ind på påvirkningen fra danske missionærer, som nok har haft betydning lokalt, men hvis Grundtvigforståelse ikke fik indflydelse på den nationale debat. I stedet vil jeg fokusere på de kinesere, der præsenterede Grundtvig for et større, læsende publikum, eller som hentede inspiration fra Danmark til deres reformprogrammer. Det danske eksempel blev især fremhævet i diskussionen om uddannelsesreformer og i forbindelse med planer om at oprette kooperativer i landsbyerne. Det var således de politiske og sociale aspekter af grundtvigianismen, der stod i centrum i Kina, og Grundtvig-fortolkningen var præget af en søgen efter direkte nytteværdi.

Artiklen vil tage udgangspunkt $i$ en Grundtvig-introduktion fra 1909, hvor det kinesiske kejserrige lå i sine sidste krampetrækninger, og følge debatten frem til dens kulmination i 1930erne, hvor Liang Shuming, en af periodens største sociale reformatorer, gennemf $\varnothing$ rte et storstilet eksperiment med opbygning af skoler og kooperativer i Shandong provinsen, delvist inspireret af den grundtvigianske model. 
Kejserrigets sidste år

Det traditionelle kinesiske uddannelsessystem, der var baseret på indterpning af de konfucianske klassikere, og hvis fornemmeste opgave var at lede frem til de kejserlige embedseksaminer, kom under hårdt pres fra reformvenlige kræfter efter Kinas ydmygende nederlag til de vestlige magter i Opiumskrigene (1840-42, 1856-60). Ønsket om at skabe et mere praktisk og teknisk orienteret uddannelsessystem efter vestligt mønster blev styrket af Kinas nederlag til Japan i krigen 1894-95, og i 1904 indførtes et skolesystem, der stort set var identisk med det japanske, som igen fulgte et vestligt, især tysk, forbillede. ${ }^{1}$ Selv om reformerne $\mathrm{i}$ de sidste årtier af Qing dynastiets levetid kun fik begrænset praktisk effekt, blev vestlige erfaringer på uddannelsesområdet præsenteret for kineserne i stor stil i denne periode, ikke mindst i tidsskriftet Uddannelse (Jiaoyu zazhi), der begyndte at udkomme i 1908.

Det var i dette tidsskrift, at kinesiske læsere i 1909 kunne læse, hvad jeg går ud fra må være den første præsentation af Grundtvig og de danske højskoler på kinesisk. ${ }^{2}$ Som så meget andet vestligt tankegods på denne tid måtte Grundtvig tage en omvej omkring Japan, idet artiklen var en oversættelse af et foredrag holdt af en japaner, dr.jur. Yahagi Eizou. I hans fremstilling var Grundtvig en uddannelsestænker, hvis væsentligste bidrag var, at han havde opdaget, at det optimale uddannelsesforl $\varnothing b$ bestod af skolegang i barndommen, praktisk arbejde $\mathrm{i}$ ungdommen og supplerende uddannelse $\mathrm{i}$ voksenårene. Højskolerne så Yahagi som en logisk konsekvens af denne pædagogiske ide.

Artiklen fremhæver det, som senere skulle blive et af kinesernes væsentligste identifikationspunkter med den danske model, nemlig den nationale ydmygelse. Ønsket om at bygge højskoler, øge uddannelsesniveauet og dermed gavne $\varnothing$ konomien fremstilles som direkte affødt af Danmarks nederlag til Prøjsen i 1864:

Som resultat [af krigen i 1864] kom Slesvig til at høre under Prøjsen. Danskerne hadede denne tilstand, og dag og nat søgte de efter en måde at hævne uretten på... Danmark var et lille land og kunne ikke få sit ønske opfyldt. Alle patrioter fyldtes af harme, men p.g.a. den store styrkeforskel var det ikke muligt for dem at nå deres mål med militære midler. De omdannede 
da al deres harme til [interesse for] uddannelse og fremmede af al magt både moralsk, intellektuel og fysisk træning, så de mand for mand kunne overgå prøjserne $\mathrm{i}$ individuel værdi og velstand. Således nåede de deres mål. Høj og lav stod sammen og trak begejstret i samme retning.

Kineserne så en parallel mellem Danmarks situation efter 1864 og deres egen i begyndelsen af det tyvende århundrede, og ideen om, at en svag, splittet og ydmyget nation gennem investering i uddannelse kunne blive forenet og stærk, stod centralt også i senere kinesiske fremstillinger af den danske model. Et væsentligt element $\mathrm{i}$ denne forestilling var højskolernes evne til at nedbryde klasseforskelle:

De studerende er for det meste børn af mellemstore jordbesiddere og af de lavere arbejdende klasser. Hjemme i deres landsbyer var de delt op i store og små, rige og fattige. Det var tit en kilde til strid mellem dem, og de var ikke nemme at forlige. Så snart de flytter ind på den samme sovesal, svinder forskellen mellem rig og fattig, fordi de fattige får et tilskud, så alle har de samme levevilkår. Da de også er jævnaldrende, lever de harmonisk sammen, og under forstanderens myndige opsyn bliver alle som en lykkelig familie.

I begyndelsen af århundredet lå det udenfor selv reformvenlige $\emptyset$ stasiaters forestillingsverden, at initiativet til en uddannelsesrevolution af denne type kunne komme fra andre end staten. Helt i denne ånd fremstiller artiklen da også højskolerne som en del af et tvungent uddannelsesforløb, som alle voksne over 21 skal igennem. Senere forfattere misforstod også højskoletanken på dette punkt, og en artikel i det meget indflydelsesrige Ny Ungdom fra 1919 fremstillede det endda, som om hele Danmarks landbefolkning blev tvangsudskrevet til højskolerne hver vinter. ${ }^{3}$

Yahagis læsere fik desuden at vide, at højskoleforstanderne var udpeget af regeringen. De »har normalt en doktorgrad" og havde absolut magt på deres skole, hvor både lærere og elever rettede sig efter dem i et og alt. Det religiøse aspekt af højskoletanken blev ikke nævnt $\mathrm{i}$ artiklen, derimod blev der lagt vægt på skolernes karakterdannende funktion, en tanke der passede fint ind i konfuciansk tankegang: 
Intet produkt kan være af prima kvalitet, hvis det ikke skabes af personer af god moralsk karakter. Derfor er træning af personligheden så vigtig... Når [det danske] erhvervsliv er så udviklet, er det et resultat af, at højskolerne har har skabt et flertal af gode borgere, som er fædrelandskærlige, ærlige og flittige.

Yahagi fremstiller således højskolerne meget positivt, men i en form der er tilpasset både hans japanske baggrund-og hans kinesiske publikum. Den stærke, velmenende stat, der sørger for befolkningens moralske opbygning får tildelt en vigtig rolle, mens selvorganiseringen, betydningen af lokale initiativer og den religiøse dimension forsvinder.

\section{Efter kejserrigets fald}

Revolutionen i 1911, som omstyrtede Qing dynastiet, styrkede tendensen til at søge efter udenlandske forbilleder og gjorde den politiske og pædagogiske debat bredere og mere nuanceret. USA, Japan, Tyskland, England og Frankrig var de store forbilleder på uddannelsesområdet, men der blev også plads til en mere detaljeret diskussion af Grundtvig og højskolerne. ${ }^{4}$ I en artikel i Uddannelse fra 1914 karakteriseredes Grundtvig ikke blot som skolemand, men også som teolog, digter og historiker, og nogle af hans pædagogiske kernebegreber blev forklaret med praktiske eksempler. ${ }^{5}$ Artiklens forfatter, der skrev under pseudonymet Jing $\mathrm{Yu}$, havde sandsynligvis været $\mathrm{i}$ Danmark. Han skildrede i det mindste højskoleundervisningen, som om han selv havde overværet den og fremhævede især de træk, der adskilte højskolerne fra den kinesiske undervisningstradition, nemlig betydningen af det talte ord, lærernes bestræbelse på at aktivere og engagere eleverne, og den ændring i elevernes grundholdning, undervisningen skabte:

[Lærerne] bruger for det meste det talte ord i klasseværelset og tvinger ikke eleverne til at lære udenad. Den, der kan komme med de vanskeligste spørgsmål til lærerens foredrag, bliver belønnet. Det ansporer eleverne intellektuelt, gør dem aktive og får dem til at stræbe efter et lykkeligt og ædelt liv... Sunde i krop og sjæl, med klareblikke og fulde af forhåbninger lytter de 
dybt koncentreret til læreren. De tager ikke mange noter, men er opmærksomme på hvert ord, så de kan udvinde hemmelighederne af de tanker, der åbenbares for dem.

En sådan undervisningsmetode lå milevidt fra kinesisk praksis. Indholdet af undervisningen i de kinesiske skoler var blevet ændret noget efter revolutionen, så de klassiske skrifter havde fået mindre betydning, mens fag som modersmålet, regning, historie og geografi havde vundet indpas. Selve undervisningsformen derimod var stadig præget af udenadslæren og absolut lærerautoritet. Akademier, hvor der kunne foregå en åben diskussion af videnskabelige og filosofiske spørgsmål, var en del af den kinesiske tradition, men dels havde de altid været forbeholdt en lille gruppe af højtuddannede, dels var det meget længe siden, de havde eksisteret $\mathrm{i}$ realiteternes verden. At bønder kunne stille spørgsmål til deres lærere, og at det var muligt, eller overhovedet $\emptyset$ nkeligt, at gøre dem til aktive og tænkende borgere, snarere end til nyttige producenter og lydige undersåtter, var endnu ikke en udbredt forestilling i Kina, selv i reformvenlige' kredse.

Højskolernes generelle styrkelse af bøndernes samfundsmæssige position blev endnu tydeligere i et afsnit, hvor Jing Yu beskrev bevægelsens politiske konsekvenser. Han kunne fortælle, at fem medlemmer af den danske regering, herunder statsministeren, var tidligere højskoleelever, og at fire af dem var bondesønner. Samme baggrund havde adskillige medlemmer af Folketinget og $80 \%$ af lederne af andelsbevægelsens virksomheder. Det må her være blevet klart for læseren, at højskoletanken ikke kun handlede om uddannelse, men også havde potentialet til at revolutionere Kinas politiske styreform. Jing Yu fik desuden understreget, at højskolerne var blevet oprettet på lokalt initiativ, selv om staten støttede dem.

I begyndelsen af 1920erne var det en fastslået kendsgerning $\mathrm{i}$ Kina, at Danmark var et absolut foregangsland indenfor folkeoplysning i almindelighed og undervisning i landområderne i særdeleshed, og Danmark nævnes konsekvent som eksempel på, hvad den type uddannelse kan føre til af politiske og $\varnothing$ konomiske fremskridt. ${ }^{6}$ Forestillingen om, at en humanistisk indstillet tænker som Grundtvig kunne skabe en bølge af åndelig vækkelse og begejstring for lærdom blandt almindelige mennesker, som igen kunne føre til et velstående og harmonisk samfund, havde fin resonans i konfuciansk tankegang. Når Danmark så oven i købet var et moderne vestligt samfund, der 
havde klaret at overleve som nation omgivet af militære stormagter, var det oplagt, at det måtte føre til noget der ligner skamrosning, som i denne præsentation af internationale erfaringer med voksenundervisning fra 1924:

Alle i hele verden kender dansk voksenuddannelse, så vi behøver ikke sige meget om den; hvis vi slet intet nævner om Danmark, vil det dog være uærbødigt overfor landets store mand, Grundtvig... Dette lille land er gennem de sidste årtier blevet Europas vigtigste landbrugsland; dets andelsbevægelse er blevet et forbillede for hele verden; dets samfundsliv og uddannelse er misundt det af ethvert land. Dette er altsammen et resultat af, at giganten Grundtvig gik ind for voksenundervising på et personlighedscentreret grundlag. ${ }^{7}$

Forfatteren til denne artikel, der selv havde besøgt Roskilde Højskole, fremhævede både Grundtvigs studier af tysk humanisme og hans kritik af denne retning, men som så mange andre holdt han religionen helt udenfor. For de fleste progressive kinesere var religion et negativt begreb, en hindring for udvikling, og en form for overtro, som netop den oplysningstanke, højskolerne repræsenterede, skulle hjælpe med at udrydde. Chen Duxiu, for eksempel, der senere blev leder af Kinas Kommunistiske Parti, skrev i 1917 en artikel med titlen »Moderne vestlig uddannelse «, hvor en af de tre hovedtendenser, han identificerede, var verdsligg $\varnothing$ relsen af de vestlige skolesystemer. ${ }^{8}$ Det var derfor naturligt for de kinesiske skribenter at se bort fra de religiøse sider af Grundtvigs tænkning, så meget mere som Grundtvig jo selv gik ind for en adskillelse af skole og kirke.

På trods af den kinesiske begejstring for ideer om voksenuddannelse på landet skete der endnu ikke meget på det praktiske plan. De fleste kræfter blev koncentreret om at virkeliggøre det nye skolesystem, der var blevet indført i 1922 efter amerikansk forbillede. Herudover var der fors $\emptyset \mathrm{g}$ med alfabetiseringskampagner, først og fremmest blandt byproletariatet, og med erhvervsuddannelse, men intet af dette havde direkte forbindelse til danske erfaringer. 


\section{Opdagelsen af landsbyerne}

Det store gennembrud for Gundtvig-interessen i Kina fandt sted i årene fra 1928 til 1931 og hang snævert sammen med de kinesiske intellektuelles opdagelse af landsbyerne som nøglen til politiske og $\emptyset$ konomiske fremskridt. Det var folk fra næsten hele det politiske spektrum, der i denne periode indså, at de fire femtedele af Kinas befolkning, som boede i landområderne, ikke længere kunne ignoreres. ${ }^{9}$ Det berømteste eksempel er nok Mao Zedong, hvis »Rapport om en undersøgelse af bondebevægelsen i Hunan« fra 1927 signalerede, at kommunisterne fra nu af ville satse mere på at opbygge baser i landområderne i stedet for at vente på, at byproletariatet skulle udvikle sig i revolutionær retning. ${ }^{10}$ Andre reformatorer af kristen, liberal og konservativ observans fik imidlertid også øjnene op for landsbyernes betydning, og den offentlige debat kom i høj grad til at handle om emner som jordreformer, kooperativer, sundhed på landet og landsbyskoler. Et af de temaer, der dominerede debatten, og som især skilte venstre- og højrefløjen, drejede sig om nødvendigheden af en social revolution. Kunne landsbyerne udvikle sig teknologisk, økonomisk, socialt og kulturelt, uden at der blev pillet ved ejendomsforholdene, eller ville det være nødvendigt først at knuse den godsejerklasse, der ikke blot ejede meget af jorden, men som også dominerede de lokale selvstyreorganer? Et andet problem var selve mobiliseringen: hvordan kunne man »vække«bønderne og gøre dem aktivt interesserede i alle de forandringer, man ville indføre? På begge disse felter kunne Danmark tilbyde tillokkende strategier og argumenter, og i slutningen af 1928 og begyndelsen af 1929 trykte kinesiske tidsskrifter en bølge af artikler om Grundtvig, højskolerne, og andelsbevægelsen."

Det er interessant at se, i hvor høj grad man opfattede den danske model som en samlet "pakke«, der indeholdt elementer som lovgivning (fra Stavnsbåndets ophævelse til statsstøtte til husmandsbrug), andelsselskaber, brugsforeninger, folkeskolen, højskoler og folkebiblioteker. Af næsten alle tekster fremgår det, at Grundtvigs tanker er den røde tråd, der løber gennem disse forskellige institutioner og binder dem sammen til en egentlig samfundsmodel. Denne opfattelse var selvfølgelig ikke skabt af kineserne selv, men afspejlede deres kilder, som først og fremmest var den engelsk- og i mindre grad tysksprogede litteratur om emnet. Bøger som Harald Wester- 
gaard: Economic Development in Denmark, Hans Lund: The Rise of the Danish Peasantry, Harold Foght: Rural Denmark and its Schools, og ikke mindst Holger Begtrup, Hans Lund og Peter Manniche: The Folk High-Schools of Denmark and the Development of a Farming Community, bidrog stærkt til Danmarks-billedet i den kinesiske debat, de to sidstnævnte ikke mindst efter de blev oversat til kinesisk i hhv. 1928 og 1931. Udenlandske fortalere for den danske model spillede også en betydningsfuld rolle. Et godt eksempel er den engelske $\emptyset$ konom J.B. Tayler, der var professor ved Yenching University i Peking, og som direkte anbefalede kinserne at lære af den danske model. I en tale, der bl.a. blev trykt i det indflydelsesrige tidsskrift $\emptyset$ sten (Dongfang zazhi), sagde han, at det bedste råd, han kunne give kineserne, var »Find Grundtvig«, og fortsatte:

De kinesiske landsbyer behøver en bevægelse som den, hr. Grundtvig anbefalede, en bevægelse, der forener moderne videnskab med ældgammel kultur, og som skaber en ny samarbejdets ånd, der kan samle folket i store og effektive sociale organisationer. ${ }^{12}$

Netop spørgsmålet om, hvad Kina kunne lære af Danmark, blev nu tacklet mere direkte. I de tidlige tekster var der en tendens til at skildre Danmark som et fjernt, lykkeligt Utopia, hvis erfaringer var interessante, men noget eksotiske. Fra 1928 blev der gjort flere fors $\emptyset \mathrm{g}$ på at finde ud af, hvad Kina kunne bruge fra modellen. Zheng Guanzhao fokuserede for eksempel på forholdet mellem lærere og elever, og priste de tætte, personlige, familiære relationer på højskolerne, som han fandt stod i grel modsætning til Kina, hvor elever og lærere var som fremmede for hinanden, og hvor skolerne var »kolde fabrikker «. I bredere forstand mente han, at det danske eksempel viste, at ægte demokrati ikke kun var et spørgsmål om at afholde valg, men at de danske bønders deltagelse i landets styrelse var blevet muliggjort af lang tids træning i demokrati på folkehøjskolerne. ${ }^{13}$

I sin anmeldelse af den kinesiske oversættelse af Harold Foghts bog fremhævede Zhu Ranli også både pædagogiske og mere generelle træk, som kineserne kunne lære af. Han bragte et langt citat med Grundtvigs kritik af »den sorte skole«, og spurgte så: 
Tillad mig at spørge: passer den kinesiske skole af idag ikke til Grundtvigs beskrivelse?... Den ikke bare minder om [den sorte skole], de ligner hinanden som to dråber vand! ${ }^{14}$

Udover at lære af Grundtvig på det pædagogiske område, mente han, at Kina skulle indse, at man måtte tage bønderne som udgangspunkt for enhver forandring. Hvis Kina slog ind på den danske vej, var der ingen ende på, hvad det kunne føre til:

Kina er fra naturens hånd et rigt landbrugsland. Hvis vi sammenligner os med det sumpede, magre, kolde Danmark, hvor de året igennem knap ser solens lys, er forskellen jo som mellem himmelens hvælv og havets dyb! Hvis Kina kunne indføre uddannelse efter den danske model ville vi kunne nå det dobbelte resultat med den halve indsats.

Personen Grundtvig blev også grundigere præsenteret for kineserne i 1928 i en lang biografisk artikel af Lei Binnan, der i denne periode var en af de flittigste skribenter om danske forhold. ${ }^{15}$ Lei havde bl.a. studeret i Berlin og på Harvard, og var en indflydelsesrig skribent og uddannelsespolitiker, som i løbet af en lang karriere bl.a. blev universitetsrektor og $\varnothing$ verste leder af uddannelsesvæsnet i Guangxi provinsen. Som led i en Europa-rejse i 1928 havde han besøgt Ryslinge Højskole, og han var også en bekendt af Peter Manniche. Allerede titlen på hans artikel, »Grundtvig, Nordens profet«, slog tonen an. Artiklen gennemgik detaljeret Grundtvigs liv, fra han sad på sin moders skød og hørte bibelske fortællinger, over hans ulykkelige forelskelse på Egeløkke til hans sidste prædiken i Vartov Kirke. For nok første gang mødte kineserne her Grundtvig som en mand, der var dybt optaget af religiøse spørgsmål. To andre træk i teksten er interessante. For det første gjorde Lei meget ud af at præsentere Grundtvig som en mand af folket, der stod i opposition til det intellektuelle establishment på universitetet:

Folkehøjskolerne... blev på ingen måde skabt af universitetsprofessorer eller -studerende. Dertil står disse herrer alt for langt fra almindelige mennesker, og deres interesse har alt for længe været adskilt fra almindelige menneskers glæder og sorger. Derfor må æren for disse skolers succes tilskrives en mand, der 
var i nær kontakt med folket. Denne mand hed Nikolaj Frederik Severin Grundtvig.

Kinesiske intellektuelle, som udgjorde Lei's publikum, var i denne periode inde $i$ en vanskelig omstillingsproces. Flertallet, selv blandt dem der var produkter af det nye uddannelsessystem, følte sig højt hævet over bønderne og stræbte efter videnskabelige og administrative stillinger i byerne. Denne holdning blev nu udfordret af de sociale reformatorer, der opfordrede de højtuddannede til at involvere sig mere direkte i landområdernes udvikling. I den forbindelse var det vigtigt for Lei at understrege, at Grundtvig ikke var en almindelig boglærd, men en socialt bevidst praktiker.

For det andet gjorde Lei hvad han kunne for at skabe identifikationpunkter mellem Grundtvig og sit kinesiske publikum. Han karakteriserede $\mathrm{fx}$ grundsætningen for Grundtvigs uddannelsestænkning med seks tegn, der kan oversættes: »I udgangspunktet er mennesket godt af natur «. Disse tegn indledte De Tre Tegns Klassiker, der var den mest udbredte læsebog i den før-moderne kinesiske skole, og tegnene har derfor for generationer af kinesere været de første, de har lært. Citatet rummede også essensen af filosoffen Mencius' tanker, og indebar dels, at alle burde have adgang til uddannelse, dels, at uddannelse var nødvendig for at holde mennesket fast på det gode. Citatet var på den måde med til at skabe en følelse af, at Grundtvigs tanker ikke var fremmede for den kinesiske humanistiske tradition.

Den Grundtvig, vi møder i denne biografi, er langt mere radikal, langt mere på folkets side imod de lærde og mægtige, end man har fået indtryk af $\mathrm{i}$ de tidligere kilder. Han er med andre ord blevet tilpasset den politiske udvikling, der er sket blandt den store gruppe af kinesiske intellektuelle, der ønskede forandring men ikke en voldelig revolution.

Samtidig med, at interessen for landområderne skærpedes i Kina omkring 1928, skabtes der altså i nogle kredse en dybere og mere detaljeret forståelse af, hvad den danske model gik ud på, og en overbevisning om, at Kina kunne bruge modellen. Den version af Danmarkshistorien, som kineserne overtog, var præget af værker, der stod højskolen og andelsbevægelsen meget nær. Af dem udledte de kinesiske samfundsreformatorer en udviklingshistorie, som de uden problemer kunne indpasse i deres eget verdensbillede: Danmarks økonomiske vækst og velstand var resultatet af en fornuftig og 
lighedsorienteret politik fra statens side kombineret med en hårdtarbejdende, oplyst bondeklasses samarbejde i andelsbevægelsen; bøndernes evne til at samarbejde og deres vilje til at tilpasse deres produktion til ny teknologi og skiftende markedsvilkår skyldtes den træning, de havde fået på højskolerne; og endelig kunne højskolernes opståen og succes tilskrives indflydelsen fra Grundtvig, som på helt enestående vis havde forstået at mobilisere danskernes kulturelle reserver. Der er en næsten mystisk kvalitet ved Grundtvigs rolle i denne proces, fordi beskrivelsen af hans aktiviteter ikke rigtig sandsynliggør den enorme betydning, han tillægges.

Opstillet på denne måde er det tydeligt, at J.B. Taylers opfordring til at »finde Grundtvig « $\mathrm{i}$ Kina havde god klangbund. Der var noget hjemmegroet og kulturelt rodfæstet ved Grundtvigs tilgang, som passede til kinesernes behov for at ændre og udvikle deres samfund uden helt at kapitulere overfor den vestlige indflydelse. Samtidig var der appel i forestillingen om en vismand, der ledte folket på rette vej. I de følgende år udpegede Kinas Grundtvig sig selv, idet Liang Shuming, en højt anset filosof og social reformator, direkte knyttede an til den danske model, da han forsøgte at omdanne et tilbagestående landbrugsområde i Shandong provinsen til et moderniseret og idealiseret kinesisk landsbyfællesskab.

\section{Liang Shuming og The Folk High Schools ${ }^{16}$}

Liang Shuming stiftede for alvor bekendtskab med danske forhold i 1931, hvor han stod foran en afgørende fase i en bemærkelsesværdig karriere. ${ }^{17}$ Liang blev født i Peking i 1893 i en familie af embedsmænd og lærde. Han far, som var en reformvenlig konfucianer, sendte ham til en moderne skole, hvor han bl.a. lærte engelsk, og mens han gik i mellemskole (1906-1911) var han meget interesseret i vestlige ideer og i reformpolitik. Efter revolutionen i 1911 blev han dybt skuffet over korruptionen i det politiske liv. Han vendte sig i stedet mod buddhismen og levede isoleret $\mathrm{i}$ sine forældres hus $\mathrm{i}$ fire år.

I 1916 brød Liang ud af isolationen og offentliggjorde en artikel om indisk filosofi, som skaffede ham en stilling som lektor ved Peking Universitet, hvad der var meget usædvanligt for en så ung mand, der ikke engang havde en universitetsgrad. Liangs virkelige 
gennembrud kom med bogen $\emptyset$ stlig og vestlig kultur og deres filosofi. Her gjorde han op med buddhismen og fremhævede istedet konfucianismen. Han indrømmede, at den vestlige civilisation havde det bedste bud på, hvordan menneskehedens materielle problemer kunne løses, men fastholdt, at det kun var den kinesiske kultur, der havde svar på de samfundsmæssige og etiske spørgsmål, og som kunne skabe personlig og social harmoni.

Desværre var den kinesiske civilisations bedste egenskaber blevet $\varnothing$ delagt af den vestlige invasion, så Kina måtte bringes til live igen, inden landet kunne fuldføre sin globale mission, eller bare redde sig selv op af dyndet. Liang mente, at uddannelse, og specielt åndelig træning, var nøglen til national genfødsel, og han så landsbyerne som det eneste sted, hvor der endnu var en smule liv i de udtørrede kulturelle rødder. Han tilbragte derfor de følgende år med at udvikle sine ideer om uddannelse og opbygning af landområderne. Han forlod sin stilling på universitetet i 1924 og arbejdede i stedet som praktisk skolemand i nogle år. I 1931 blev han inviteret til Shandong af en af sine magtfulde velyndere, provinsguvernør Han Fuqu, en krigsherre, der formelt var underordnet Nationalistregeringen, men som i realiteten havde næsten uindskrænket magt i sin provins. Liang blev udnævnt til leder af et nyoprettet Institut til Genopbygning af Landområderne, der blev placeret i Zouping, et amt med godt 150.000 indbyggere. Instituttets væsentligste funktion var at igangsætte en social, politisk og $\varnothing$ konomisk modernisering af dette område, der kort tid efter blev til »fors øgsamt «, hvad der i praksis betød, at Liang og hans medarbejdere fik frie hænder til at indføre administrative reformer, der gik ud over de centralt fastsatte regler.

Det var netop i 1931, mens Liang Shuming for alvor var i gang med at overveje, hvordan hans ideer kunne omplantes til Zoupings virkelighed, at han i detaljer satte sig ind i de danske erfaringer. Som næunt udkom The Folk High-Schools of Denmark and the Development of a Farming Community i kinesisk oversættelse i 1931. Bogen, som var skrevet af de tre fremtrædende højskolefolk Holger Begtrup, Hans Lund og Peter Manniche, indeholdt en begejstret og optimistisk skildring af højskolernes historiske og samtidige betydning. I oktober samme år offentliggjorde Liang Shuming i tidsskriftet Landsbystyre (Cunzhi yuekan) en anmeldelse af bogen, som udviklede sig til en lang diskussion af konsekvenserne af de danske erfaringer for kinesisk uddannelsespolitik. Anmeldelsen, der fik titlen »Dansk uddannel- 
se og vores uddannelse «, blev lidt af en klassiker i Liangs forfatterskab om uddannelsesspørgsmål og er blevet genoptrykt i alle senere samlinger af hans skrifter om dette emne. ${ }^{18}$

Selv om Liang også nævner Danmark i enkelte tidligere skrifter, tyder alt på, at hans første grundige indføring i emnet har været The Folk High-Schools. I anmeldelsen fastslår han først, at den "grundlæggende ånd « i dansk uddannelse ikke havde noget at gøre med undervisning i landbrugsfag eller i kooperation, som han ellers havde forventet $\mathrm{i}$ et land, der var berømt for sit landbrug. Vægten lå heller ikke på boglig lærdom. I stedet var der tale om en åndelig vækkelse, hvor »...et mindretals ånd havde vækket flertallets«. At moralsk og åndelig uddannelse skulle spille hovedrollen var helt i overensstemmelse med Liangs egne ideer, og det skilte i hans øjne Danmark ud fra resten af den vestlige verden. For eksempel havde han i 1922 i artiklen »Forskelle på østlig og vestlig uddannelse « hævdet at vestlig uddannelse var kendetegnet af systematisk formidling af viden om det konkrete, mens $\varnothing$ stlig uddannelse havde sin styrke i den etiske opdragelse. ${ }^{19}$ I den sammenhæng var højskolerne klart mere » $\varnothing$ st« end »vest «.

Netop spørgsmålet om praktisk/faglig eller åndelig/almen uddannelse havde fået bogens oversætter, Meng Xiancheng, der selv var en kendt uddannelsesreformator, til at skrive et forord, hvor han mindede om, at den ikke-fagrettede undervisning på højskolerne ikke betød, at danskerne overså betydningen af landbrugsfag, men blot, at disse fag hørte til i et andet regi, nemlig på landbrugsskolerne. Han tilføjede, at Kinas fattigdom tvang landet til at give undervisningen i nye dyrkningsmetoder $h \varnothing j$ prioritet, fordi befolkningen ellers ville komme til at sulte. Liang var uenig og gav Meng denne salut med på vejen:

Desværre har hr. Meng, da han oversatte bogen, tilføjet nogle overflødige og indlysende bemærkninger i sit forord. De hjælper ikke læseren til at nå en dybere forståelse, svækker originalens oprindelige skønhed og $\mathrm{g} \emptyset \mathrm{r}$ hans eget arbejde som oversætter mindre værdifuldt.

Liang gik herefter over til at præsentere bogens tre hovedpersoner: Grundtvig, Christen Kold og Ludvig Schrøder. Bogens indledende beskrivelse af Grundtvig vakte Liangs begejstring i en sådan grad, at 
han citerede den to gange $\mathrm{i}$ anmeldelsen. I den engelske original lød den:

The idea which gave them [i.e. højskolerne] birth was not conceived in the mind of a college professor; it was conceived in that of a prophet, a spiritual genius who understood the life and mind of his people throughout the ages, and who thereby had the vision of the special enlightenment that was needed to promote the well-being of his people.

Liang havde klare forestillinger om sig selv som Kinas profet og frelser og har uden tvivl kunnet identificere sig med skildringen af Grundtvig i samme rolle i Danmark. De to havde faktisk meget tilfælles. De gennemgik begge alvorlige psykologiske kriser i deres ungdom, som de kom ud af med stærke visioner om deres egen historiske mission. De vendte sig begge, ihvertfald midlertidigt, fra lovende akademiske karrierer for at arbejde blandt bønder, som de mente, besad nøglen til deres lands fremtid. Ligesom Grundtvig trak på den nordiske mytologi for at finde billeder, der kunne anspore til national genfødsel, brugte Liang et idealiseret billede af Kinas før moderne kultur og samfund som forbillede. Og som Grundtvig modsatte sig latinens herredømme i den danske skole, vendte Liang sig imod fremmed dominans over kinesisk uddannelse.

Liang nævner alle disse aspekter af Grundtvigs liv og ideologi i sin anmeldelse, men hvad der imponerede ham mest, var beskrivelsen af, hvordan Grundtvig øvede afgørende indflydelse på dansk politisk og økonomisk liv uden direkte at blive indblandet $\mathrm{i}$ det almindelige politiske slagsmål. Det kunne lade sig gøre, mente Liang, fordi Grundtvigs drivkraft ikke var et $\emptyset$ nske om at løse sit folks umiddelbare problemer, men snarere en livsfilosofi og en religøs tro. Liang havde selv en meget blandet holdning til politisk magt, og hans respekt for politikere var stærkt begrænset, så Grundtvigs ophøjede rolle appellerede stærkt til ham.

Hos Kold fandt Liang andre egenskaber, der svarede til hans egne idealer, især den simple livsstil: »I sandhed! Kun en simpel fremtræden rummer virkelige dybder; ydre pragt er kun bevis på åndeligt armod«, lød Liangs kommentar. Denne pointe havde han ofte selv fremhævet i sine taler til mellemskoleelever, der på det tidspunkt næsten alle tilhørte en priviligeret overklasse. Liang roste også Kolds 
evne til inspirere sine studerende. Hos Schrøder var han især tiltalt af evnen til at forene praktisk, jordbundet arbejde, som indførelsen af nye afgrøder, med de højeste åndelige idealer.

Liang opregnede otte punkter, hvor højskolerne kunne tjene til inspiration: 1) Skolerne blev stiftet på den lokale befolknings eget initiativ, og de var ikke kun undervisningsanstalter, men også arnested for andelsbevægelsen og centrum for hele egnens sociale og kulturelle liv. 2) Eleverne var ikke børn, men unge voksne med en vis livserfaring og grundlæggende uddannelse bag sig. 3) Skolerne blev styret af private, og eleverne meldte sig frivilligt. 4) Staten st $\varnothing$ ttede skolerne $\varnothing$ konomisk, men prøvede ikke at kontrollere dem. 5) Atmosfæren på en højskole var som i en familie. 6) Eleverne og lærerne var venner. 7) Undervisningen var baseret på diskussioner. 8) Der var ingen fast læseplan; i stedet blev der oprettet fag efter behov.

Liang spurgte nu sig selv, hvad Kina kunne lære af disse træk. Han mente, at kinesisk uddannelse var inde $\mathrm{i}$ en overgangsperiode. Efter den vestlige indtrængen i det 19. århundrede havde Kina efterlignet Vesten, og da den vestlige civilisation var knyttet til byerne og baseret på håndværk og handel, måtte det importerede skolesystem nødvendigvis få samme orientering mod byerne. For at indhente Vesten teknologisk havde Kina desuden primært investeret $\mathrm{i}$ at træne en lille elite, som man så håbede ville videreformidle vestlig viden til hjemlandet. Imidlertid var der nu mange, heriblandt Liang selv, der indså, at man i stedet måtte satse på masseuddannelse og på landområderne. Det betød, at Kina pludselig stod i samme situation, som Danmark havde gjort firs år tidligere, så selv om man aldrig skulle kopiere udlandet direkte, burde Kina udnytte muligheden for at få svar på to spørgsmål fra danskerne: 1) Skal uddannelse dreje sig om viden og færdigheder, eller om hvordan man lever et rent og retfærdigt liv? 2) Skal initiativet ligge hos staten eller hos private kræfter? I begge disse spørgsmål havde Danmark ifølge Liang valgt den sidstnæunte mulighed, mens kineserne $\mathrm{i}$ de forløbne 30 år havde valgt den førstnævnte, og i begge tilfælde havde kineserne valgt forkert.

Hvad det første punkt angik, kunne Kina ikke udnytte den udenlandske viden og teknologi, skrev Liang, fordi den kinesiske kultur var som et dødt træ, som man ikke kunne pode nye grene på. Kineserne, og især bønderne, der var de sande bærere af kulturen, måtte først bringes til live igen. Alle kampagner for at lære folk at læse og 
skrive eller for at indføre nye landbrugsmetoder ville løbe ud i sandet, indtil en »stor lærer med dyb tro og stærk vilje« ville oplyse folket og lede det frem mod dybtgående mentale ændringer.

Spørgsmålet om privat initiativ var lige så vigtigt for Liang. Moderne uddannelse var blevet bragt til Kina udefra, uden at den kinesiske befolkning selv havde følt noget behov for at ændre det gamle system. Derfor var det staten, der havde måttet tage initiativet. Men statslig uddannelse har ingen livsnerve, mente Liang, den er mekanisk. Han havde en række indvendinger mod statsdrevne skoler: 1) De var formalistiske. Da den kinesiske stat for eksempel beordrede amterne til at oprette moderne skoler omkring århundredeskiftet, havde embedsmændene bare sat et nyt navneskilt op over den lokale skoles indgang, mens indholdet forblev det samme. 2) De var ensrettede og skulle overholde alle mulige love og forordninger, mens det, der var brug for i Kina, var eksperimenter og tilpasning til lokale forhold. 3) Staten påtvang lokalsamfundene typer af uddannelse, som der ikke var behov for. 4) Statslige skoler var ødsle. Lokalsamfundene kan gennemføre undervisning langt mere $\emptyset$ konomisk. Staten skulle støtte og belønne privat initiativ, og træde til i nødstilfælde, hvis et lokalsamfund ikke magtede opgaven, men den skulle ikke spille en hovedrolle, eller ligefrem stille sig i vejen for lokale tiltag, som det nu ofte var tilfældet.

\section{Liangs фvrige skrifter om Danmark}

Andre af Liangs artikler kaster yderligere lys over den rolle, som Grundtvig og Danmark spillede for ham. Omkring samme tid som anmeldelsen af The Danish Folk High Schools udkom, holdt han en tale $\mathrm{i}$ anledning af Japans invasion af Manchuriet. ${ }^{20}$ Her sagde han, at de japanske krigsmagere nøjedes med at besvare udfordringen fra den vestlige civilisation ved at efterabe den. P.g.a. sit høje civilisatoriske stade havde Kina derimod $\mathrm{i}$ årtusinder vist sig $\mathrm{i}$ stand til fredeligt at indoptage og omforme udenlandske aggressorer i sit eget billede, og landet skulle fortsat sætte sig til modværge ikke primært med militær magt men ved at udvikle sin lixing, som var blevet alvorligt svækket i moderne tid. Lixing var et nøglebegreb for Liang, essensen af Kinas bidrag til verden, og henviste både til fornuft og rationalitet (som er ordets ordbogsbetydning) og til evnen til at indgå 
i mellemmenneskelige forhold på grundlag af de højeste etiske principper. Konkret mente Liang, at Kinas største problem var dets mangel på social sammenhængskraft og lixing, og han næunte to udenlandske pionerer, som Kina kunne lære af med hensyn til fredelig opbygning af en nation: Gandhi i Indien og Grundtvig i Danmark. I den sammenhæng skrev han:

[Danmarks] areal er lille, men det overgås ikke i velstand af nogen anden nation. Dets sociale forhold er yderst stabile, der er ingen kampe mellem arbejdere og kapitalister, og landets rigdomme er ligeligt fordelt. Hvordan har de opnået det? Ikke ved at besejre andre nationer, men gennem uddannelse... Denne civilisation er resultatet af en gammel skolemands anstrengelser: Grundtvig... Grundtvig hævede den almindelige danskers niveau, han sørgede for at borgerne fik lixing, og det var derfor landet begyndte at blomstre igen.

Ved at bruge begrebet lixing, den kinesiske kulturs adelsmærke, om indholdet i den danske model, var Liang godt på vej til at holde Danmark frem som sit eget private Utopia. Igen er det tydeligt, at han ikke opfattede det landlige, fredelige Danmark som en del af det urbaniserede, industrialiserede og aggressive Europa.

Liangs næste omfattende diskussion af Danmark kom i en text fra 1934, »Essensen af åndelig træning «, hvor han gentog mange af pointerne fra anmeldelsen. ${ }^{21}$ Her kom han imidlertid også for første gang ind på forskellene mellem Danmark og Kina. Han mente, at det ville blive langt vanskeligere at genopbygge Kina, end det havde været i Grundtvigs Danmark. I Danmark havde nederlaget til Tyskland været det største problem, og den nationale genopvågnen var blevet skabt af kirkens folk, som kunne benytte sig af folkets latente religiøse følelser. Sådanne følelser kunne vækkes gennem litteratur, heltefortællinger, musik og sang. Det kinesiske folk havde mere grundlæggende problemer, som de ovenikøbet måtte løse i en langt mere skeptisk tidsalder, hvor værdisystemerne ikke bare i Kina men over hele verden var blevet rystet i deres grundvold. Den afgørende forskel var imidlertid, at kinesisk kultur ikke var religiøs, men baseret på lixing. Derfor skulle der rationelle argumenter og diskussioner af de dybeste eksistentielle spørgsmål til for at vække kineserne, det kunne ikke klares med et par velvalgte sange, som i danskernes 
tilfælde. På den anden side var det netop kinesernes etiske og rationelle holdning, der ville gøre det muligt for dem at overvinde problemer af en helt anden størrelsesorden end danskernes.

\section{Personlige møder}

Ved mindst to lejligheder havde Liang Shuming mulighed for at diskutere sine visioner med fremtrædende repræsentanter for den danske højskolebevægelse. Kontakterne startede i 1934, da Peter Manniche, rektor for Den Internationale Højskole i Helsingør, kom til Kina på en foredragsturne, der bragte ham til adskillige lande. ${ }^{22}$ I Kina besøgte han Hong Kong, Canton, Shanghai, Wuxi, Jinan, Tianjin, Peking og en række landområder. Bare i Shanghai holdt han 50 foredrag i løbet af seks uger, og han fandt ud af, at både embedsmænd og intellektuelle var yderst interesserede i, hvad han havde at fortælle. Han mente det skyldtes, at den kinesiske oversættelse af The Danish Folk High Schools havde vakt betydelig opmærksomhed. Den var allerede blevet solgt i 5.000 eksemplarer og skulle snart udkomme i en ny udgave. Han aftalte endda med det førende Shanghai forlag Commercial Press, at de skulle udgive en forsættelse, som han ville skrive på vejen tilbage til Danmark.

I Jinan, Shandong provinsens hovedstad, blev Manniche modtaget af Liangs magtfulde bagmand, guvernør Han Fuqu, som havde fået samlet ikke mindre end 2.000 militære og civile embedsmænd til at overvære Manniches foredrag klokken syv om morgenen om dansk jordpolitik. Manniche nævner ikke, om han mødte Liang ved denne lejlighed, men han blev ihvertfald informeret om Liangs projekt i Zouping, for i sin rapport til Udenrigsministeriet i Danmark skrev han senere, at den bedste måde, hvorpå folkehøjskolens mål og metoder kunne omplantes til kinesisk jord, ville være gennem private skoler med støtte fra provinsregeringer, og han nævnte tre særligt lovende fors $\emptyset \mathrm{g}$ af denne type, hvoraf det ene var »Professor Liangs skole i Chouping [i.e. Zouping], der er en smuk moderne Repræsentant for Fortidens System, der paa godt og ondt gav den lærde Ansvaret for Administrationen og det praktiske Erhvervsliv«.

Under sit besøg blev Manniche opfordret til at sende flere højskoleeksperter som konsulenter til Kina, og da han vendte hjem, udvalgte han to lærere fra Askov Højskole, S. Juul Andersen og J.U.S. 
Balslev, til denne opgave. De besøgte i september 1934 Zouping, og deres samtaler med Liang Shuming, som senere blev grundigt refereret i tidsskriftet Genopbygning af Landområderne (Xiangcun jianshe) giver et førstehåndsindtryk af mødet mellem reformorienteret konfucianisme og den danske model. ${ }^{23}$

Liang indledte interviewet med at understrege Danmarks særstatus i Europa og dets lighedspunkter med Kina:

I Kina bruger vi tit forholdet mellem far og $s ø n$ og mellem ældre og yngre brødre til at beskrive også forhold udenfor familien, så vi omtaler embedsmænd og læremestre som vores fædre og nære venner som vores brødre. Efter hvad jeg har hørt, minder det meget om atmosfæren på en dansk højskole eller $\mathrm{i}$ et andelsforetagende. Vi synes tit, at der er for meget konkurrence mellem vesterlændinge og for lidt venskab, men nu har vi i Danmark fundet et samfund, hvor alle er venner, og hvor der ingen indbyrdes konkurrence er.

Balslev svarede, at ikke blot var der ingen konkurrence mellem enkeltpersoner, men heller ikke klassekamp eller politisk kamp kendte man til i Danmark. Der var næsten ingen arbejdsløshed, og landmændene var altid villige til at hjælpe arbejderne, hvis de var i nød. Disse to sociale grupper delte også fredeligt den politiske magt mellem sig. Således forsikret om, at alt stod vel til i hans fjerne Utopia, fortsatte Liang med at fremlægge sit syn på konfucianismen og dens rolle i den kinesiske kultur. De to danskere var tilsyneladende imponerede over, hvad de så og hørte, og gav begge udtryk for, at de ingen andre steder i Kina havde fundet noget, der lignede Danmark så meget som Zouping eksperimentet.

I slutningen af januar 1936 kom Peter Manniche selv til Zouping. Der findes ingen referater af hans samtaler med Liang, men Manniche var overbevist om, at den danske model var relevant for, hvad der senere kom til at hedde udviklingslandene, og der er næppe tvivl om, at han gjorde, hvad han kunne, for at befæste Liangs tillid til den. Manniches egne notater fra turen viser, at han til gengæld også var imponeret af sin vært: 
Liang havde grundigt studeret de danske Folkehøjskoler, og en af hans Bestræbelser var at oprette Højskoler til Uddannelse af Ledere i Landdistrikterne, og navnlig Foregangsmænd indenfor Kooperation og Andelsbevægelse... [Zouping] er Kinas eget Fors $\varnothing \mathrm{g}$ paa at forny sig selv. Da jeg talte med ham [i.e. Liang] i den store men gammeldags kinesiske Gaard, hvor han boede... sad nogle af Distriktets højeste Embedsmænd, der alle var hans Disciple, og lyttede ærbødigt til hans ord. ${ }^{24}$

Under disse møder præsenterede begge parter således et idealiseret billede af sig selv, og den konfucianske vismand og Den tredje Vejs forkyndere befandt sig godt i hinandens selskab.

\section{Liangs skolesamfund i Zouping}

Fra sin ankomst til Zouping i 1931 og frem til 1937, hvor den japanske invasion satte en stopper for hans aktiviteter, havde Liang Shuming forholdsvis frie hænder til at indrette amtet efter sine egne ideer. Da disse ideer, som vi har set, lå tæt op ad højskoletanken, er det interessant at se, hvordan de blev udmøntet i praksis. Først skal det dog understreges, at Liang ikke kan beskyldes for at kopiere den danske model. Hans strategi lå i hovedtrækkene klar allerede inden han stiftede bekendtskab med Danmark og var resultatet af hans egen analyse af Kinas situation. Selv de træk, der umiddelbart ser ud, som om de er hentet direkte fra højskolerne, som fx fællessangen og skolelederens daglige morgentale til eleverne, havde Liang foreslået og praktiseret, før han kendte noget til Danmark. Der var snarere tale om, at Liang i det danske eksempel fandt bekræftelsen på, at han havde ret, og specielt på, at hans specielle opfattelse af sammenhængen mellem åndelig vækkelse, social organisering og uddannelse var korrekt og måske endog havde universel gyldighed.

Kernen i Liangs reorganisering af Zouping var landsby- og distriktsskoler, der ikke blot var tænkt som uddannelsesinstitutioner, men som administrative, politiske og kulturelle centre. ${ }^{25}$ Disse skoler var samtidig Liangs mest originale bidrag til diskussionen om, hvordan Kinas landsbyer kunne moderniseres. Initiativet til oprettelsen af en landsbyskole kom som regel oppefra, fra aktivisterne i Institut til Genopbygning af Landområderne. Når de kom til en 
landsby undersøgte de først omhyggeligt de lokale forhold og udvalgte derefter syv-otte velansete og som regel også velhavende mænd til et skoleråd. En af dem blev udnævnt til administrator og fik ansvaret for landsbyens affærer og for dens forhold til amtsregeringen. Derudover blev der udpeget en »skoleleder«, som regel en ældre herre kendt for sin visdom og moralske habitus. Han skulle overvåge skolerådets virksomhed og fungere som mægler mellem rådet og landsbyens beboere, så det ikke kom til åbne konflikter og konfrontationer. Når denne struktur var på plads, blev der udsendt en lærer fra instituttet. Han skulle stå for den konkrete undervisning, evt. sammen med den oprindelige landsbylærer, hvis en sådan fandtes, og skulle desuden videreformidle amtsregeringens politiske tiltag og kampagner. Alle andre i landsbyen, uanset alder og køn, blev kaldt »elever «.

Hele landsbyens ledelses- og magtstruktur blev således indskrevet i en uddannelsesmetafor, hvor ledelsens autoritet $\mathrm{i}$ teorien bundede $\mathrm{i}$ lærdom, snarere end i ejendom, social position eller alder. Liang kunne godt se, at der var sociale forskelle i landsbyerne, som blev domineret af de mere velhavende bønder, men modsat Mao og kommunisterne mente han ikke, at klassemodsætningerne var hovedproblemet, og troede heller ikke på, at man for alvor kunne modernisere uden elitens medvirken.

Landsbyskolerne skulle være de levende celler, som Liangs ny-traditionelle Kina blev bygget af. Som et resultat af det fællesskab, som skolerne ville skabe, skulle der dannes kooperativer, især for bomulds- og silkeproducenter, og oprettes lånekasser, der skulle dæmpe den ågervirksomhed, der var et stort socialt problem. Der skulle også organiseres selvforsvarsgrupper til beskyttelse mod de mange røverbander, der hærgede egnen, og føres kampagner mod, hvad Liang anså for at være forældede sæder og skikke, først og fremmest indsnøring af pigernes fødder (stadig vidt udbredt i Shandong i 1930erne), opiumsrygning, børneægteskaber og »sjofle « teaterstykker. Centralt stod selvfølgelig også egentlige undervisningsforløb, både af landbrugsteknisk og mere almen karakter.

Distriktsskolerne rolle lignede landsbyskolernes, blot på et højere niveau. De skulle bl.a. tage sig af konflikter mellem landsbyer, større anlægsprojekter og undervisning af det fătal, der fortsatte skolegangen ud over de fire klassetrin, der normalt blev tilbudt af landsbyskolerne. 


\section{Voksenundervisning i Zouping}

Pladsen tillader ikke en detaljeret behandling af alle disse tiltag, men da voksenundervisningen var mest direkte inspireret fra Danmark og desuden stod meget centralt i Liangs strategi, er den af særlig interesse her. ${ }^{26}$

Liangs første udspil på dette felt kom allerede i 1931, d.v.s. inden landsbyskolerne var begyndt at fungere, med oprettelsen af såkaldte landboskoler (xiangnong xuexiao). De tilbød et tre måneders kursus i vinterperioden, og fagrækken var enkel: åndelig træning (d.v.s. Liangs egne ideer), partilære (d.v.s. Nationalistpartiets ideologi), læsning, selvforsvar og landbrugsfag. For det mindretal, der allerede kunne læse, var der desuden kurser i litteratur, historie og geografi. Disse skoler fik næsten 4.000 elever i 1931, men de var helt afhængige af, at studerende ved Institut for Genopbygning af Landområderne organiserede og gennemførte undervisningen som en del af deres praktikperiode det år. Allerede i 1932 blev praktikanterne imidlertid i stedet spredt ud til de mange amter, der havde sendt dem, og de fleste af landboskolerne i Zouping blev opløst. Fra 1933 blev det i stedet pålagt landsbyskolerne at oprette aftenkurser for voksne, men der manglede detaljerede retningslinjer for, hvordan denne undervisning skulle foregå. Kurserne blev generelt mødt med ligegyldighed og frafaldet var stort.

Herefter blev meget af undervisningen koncentreret om unge mænd mellem 18 og 30, som skulle indgå i den lokale milits, der skulle forsvare Zouping mod røverbander og samtidig opretholde ro og orden i deres respektive landsbyer. Allerede omkring rekrutteringen til disse kurser var der store problemer. Selv om undervisningen lagde mere vægt på politisk og almen uddannelse end på egentlig militær træning, havde landsbyerne erfaring for, at de statslige myndigheder og deres agenter på amtsplan kun interesserede sig for dem, når der skulle udskrives skatter eller rekrutteres soldater, og de fortolkede Liangs kurser som et kun let maskeret fors $\emptyset \mathrm{g}$ på at hverve en lokal hær. Resultatet var, at mange nægtede at møde op. De der trods alt fulgte det to måneders kursus $\mathrm{i}$ amtshovedstaden udviklede til gengæld hurtigt en voldsom følelse af overlegenhed overfor de landsbyfæller, der ikke havde gennemgået moderne træning, og udnyttede ofte deres magtposition på det groveste, når de vendte tilbage. 
Disse forholdsvis nedslående erfaringer førte til, at man dels opgav frivillighedsprincippet, som var blevet fulgt i aftenskolerne, dels valgte at sprede milits-træningen ud til landsbyerne, for at undgå at opholdet i amtsbyen fjernede de unge fra deres eget miljø. I 1935 fors $\emptyset$ gte bevægelsen sig derfor med »obligatoriske ungdomskurser «, som alle i den relevante aldersgruppe blev tvunget til at deltage i. Fagrækken omfattede læsetræning, musik, almen viden om natur og landbrug, militær træning, kampteknik og samfundsfag (d.v.s. Liangs ideer om opbygning af landområderne). Det første kursus skulle have varet i seks måneder, men blev mødt med så massiv modstand, at det måtte skæres ned til en enkelt måned. Nogle elever pjækkede, andre udspredte rygter om, at træningen var så hård, at den havde ført til dødsfald blandt kursisterne, mens andre igen larmede og råbte udenfor lærerens hus tidligt om morgenen for at gøre livet surt for den arme mand, der skulle undervise dem morgen og aften ved siden af sit almindelig job som lærer i børneskolen midt på dagen.

Fra 1936 blev der også indført obligatorisk aftenskole i to ti-ugers perioder om året for alle mænd mellem 16 og 40. I Instituttets første år havde der lydt begejstrede beskrivelser af, hvordan unge og gamle, fattige og rige stimlede sammen i skolerne for at suge til sig af den tilbudte lærdom. Nu var tonen blevet en anden:

Vi fastholder hr. Wang Binchengs [en af bevægelsens ledere] holdning: »Dem vi siger skal møde op [i skole] skal møde op, og de skal ikke gå igen, før vi har givet dem lov til det«. Undervisningen er tvungen og almen, for befolkningen i landsbyerne er doven og sløset, uden organisation og vilje. [Man kan] sammenligne dem med sten: lidt blæst og regn vil ikke rokke dem ud af stedet. Hvis det var frivilligt at komme, ville der muligvis ikke dukke en sjæl op. Hvis de måtte gå, når de havde lyst, sad der måske ikke en sjæl tilbage. I den vanskelige situation vort land er i, kan vi ikke blive ved med at holde skole, som om det var et tehus! $!^{27}$

Mellem 1931 og 1937 underviste Liang Shumings bevægelse ialt 15.000 kursister i almene, landbrugsfaglige og militære fag, og der er ingen tvivl om, at disse kurser har haft stor betydning for uddannelsesniveauet i Zouping amt. En række af bevægelsens tiltag har også tydelige lighedstræk med den danske model, fx vægten på almene fag 
og integrationen af uddannelse og kooperation, mens andre, som den militære træning, er præget af Kinas specielle situation på daværende tidspunkt. Det er imidlertid også iøjnefaldende, at der er stor forskel mellem Zoupings virkelighed på den ene side og både højskoletanken og Liangs egne idealer på den anden. Kernen er her spørgsmålet om tvang og frivillighed, eller mere generelt om forholdet mellem statsmagten og det lokale samfund. Da Liang Shuming i 1935 evaluerede bevægelsens resultater, fremhævede han to hovedårsager til, at Zouping ikke kunne kaldes en succes. ${ }^{28}$ For det første havde han været nødt til at støtte sig til staten i alt for $h ø j$ grad, fordi han ellers hverken ville have haft $\varnothing$ konomisk eller politisk grundlag for at operere. I virkeligheden kom Liangs bevægelse til at fungere som den moderniserende stats forlængede arm ud i landområderne, på trods af hans egen voldsomme skepsis overfor statens rolle på uddannelsesområdet. For det andet var han klar over, at bønderne aldrig var blevet andet end objektet for reformerne, mens de intellektuelle $\mathrm{i}$ bevægelsen var det aktive subjekt. De fleste ændringer var blevet påtvunget bønderne enten mod deres ønske, eller ihvertfald uden at de selv havde formuleret et behov for at lave noget om. I den forstand var selve ånden i den danske model, det der primært havde fascineret Liang ved Grundtvig og hans tilhængere, smuldret mellem fingrene på ham på trods af alle gode intentioner.

Da japanerne i 1937 rykkede ind i Shandong, og Liang måtte opgive at videreføre sit eksperiment, havde han stadig tillid til sin egen grundlæggende teori. Han kom dog aldrig mere til at spille en aktiv rolle på uddannelsesområdet. Han forblev på det kinesiske fastland efter 1949, hvor det kommunistiske styre lod ham indtage en forholdsvis høj position indtil 1953, hvor han havde et større sammenst $\varnothing \mathrm{d}$ med Mao Zedong, som han beskyldte for at favorisere byerne på landområdernes bekostning. Frem til sin død i 1988 beskæftigede Liang sig herefter igen fortrinsvis med kulturteori og fik ikke flere chancer for at føre sine praktiske ideer ud i livet. Den kommunistiske jordreform og senere kollektivisering, der lagde vægt på netop de klassemodsætninger, som Liang havde anset for uvigtige og skadelige, førte til en helt anden udvikling i Kinas landsbyer, end den han havde drømt om. Omkring 1937 holdt han, og de kinesiske samfundsdebatører som helhed, tilsyneladende også op med at interessere sig for Grundtvig og Danmark. Den eneste væsentlige undtagelse ser ud til at have været Lei Binnan, der endnu midt i 1940er- 
ne fremhævede de danske højskoler, og som i Guangxi startede en række skoler, der fulgte nogle af de samme ideer. Generelt var Kina på dette tidspunkt dog alt for optaget af krig og borgerkrig til at modellen fik videre udbredelse, og efter kommunisternes sejr i 1949 blev Sovjetunionen det store forbillede, også på skoleområdet.

\section{Konklusion}

Det umiddelbart slående ved den kinesiske diskurs om Grundtvig, højskoler og andelsbevægelse i begyndelsen af dette århundrede er dens omfang og kvalitet. Især i perioden fra slutningen af 1920erne til midt i 1930erne stod det danske eksempel centralt i den kinesiske uddannelsesdebat og havde også indflydelse på diskussionen om opbygningen af landområderne mere generelt. De fleste reformorienterede skole- og kooperationsfolk har kendt den danske model, og blandt dens direkte fortalere befandt sig markante og indflydelsesrige personligheder. Foruden Lei Binnan og Liang Shuming kan nævnes Yu Qingtang, der var rektor for et seminarium i Wuxi og en kendt skribent. Hun besøgte Den Internationale Højskole i 1933 og fremstillede i sine skrifter de danske erfaringer i meget positive vendinger. ${ }^{29}$ Interessen for Danmark var $\mathrm{i}$ denne periode en væsentlig strømning, hvor den før og siden mere havde karakter af et supplement til informationen om de store vestlige lande.

Dernæst er det tydeligt, at det billede, kineserne fik, ikke var tilfældigt, og heller ikke var baseret på deres egne direkte erfaringer med dansk virkelighed. Det var primært skabt af en engelsksproget litteratur af forholdsvis få forfattere, som alle var knyttet til selve højskolebevægelsen, og som så det som en vigtig opgave at fremme internationaliseringen af den danske model. Oversættelsen til kinesisk af nogle få hovedværker satte for alvor skub i udviklingen. Danmarksbilledet i disse værker var udtryk for en fortolkning af den nationale historie, der lagde vægt på social lighed, national bevidsthed og, først og fremmest, harmoni og balance mellem samfundsklasserne og mellem stat og samfund. Konflikter på arbejdsmarkedet, arbejdsløshed, sociale problemer, og interessemodsætninger mellem by- og landbefolkning og mellem de politiske partier, der repræsenterede dem, var også en del af virkeligheden i 20ernes og 30ernes Danmark, men blev bortretoucheret fra det billede, der vistes udadtil. 
Resultatet var, at kineserne, som vi har set det med Liang Shuming, fik indtryk af, at Danmark på forunderlig vis stod udenfor, eller nærmere var hævet over, de modsætningspar, der dannede tidens kinesiske verdensbillede: kapitalisme og socialisme, østlig og vestlig kultur, by og land, modernitet og tradition. Danmark, koncentreret i Grundtvigs person, stod for en tredje vej, hvor spørgsmålet om magt, både politisk og militær, stort set var blevet ophævet af en national og kulturel vækkelse af næsten mystisk karakter.

Liangs vanskeligheder med at realisere højskoletanken i Zouping kan begrundes på mange måder, bl.a. med de kaotiske tilstande $\mathrm{i}$ Kina i 1930erne og med japanernes indtrængen. Måske var det kun historiske tilfældigheder, der forhindrede ham $\mathrm{i}$ at give sin model større udbredelse. Hans erfaringer viser dog også hen til mere grundlæggende vanskeligheder ved denne tidlige systemeksport. I Danmark kunne højskolerne drage fordel af, at der var blevet indført almen undervisningspligt allerede i 1814, så langt de fleste voksne kunne læse og skrive, hvad der sandsynligvis i sig selv har skabt et vist behov for mere viden. Folk i Zouping havde ikke en tilsvarende baggrund, og de kinesiske skrifttegn gjorde selve læseindlæringen til en mere langsommelig proces. Desuden var højskolernes undervisningsform helt fremmed for Kina, hvor uddannelse altid havde været (og stadig er) snævert forbundet med at gå til eksamen, avancere $\mathrm{i}$ samfundet og slippe bort fra landområderne. Netop det faktum, at højskoletanken udgjorde et modbillede til den kinesiske tradition, har på een gang gjort den tiltrækkende og svær at realisere.

Mere fundamentalt blev oplysningsaspektet blandet sammen med social kontrol og styring på en ødelæggende måde. Landsbyskolerne forudsatte den enighed og harmoni, som de selv skulle skabe. I det øjeblik nogle bønder forholdt sig skeptisk til reformerne, skiftede skolerne ansigt og blev kontrolorganer med administrativ magt til at gennemtvinge beslutninger. Derved fik landsbyernes eliter, som bevidst var indplaceret som ledere af skolerne, endnu større magt, end de havde haft før reformerne. I Danmark blomstrede højskolerne op i et samspil med en stadig mere politisk bevidst og velorganiseret klasse af selvejende bønder og var i den forstand led i en social og politisk kamp om samfundsmagten, samtidig med at de var del af en national bølge. Kommunisternes sejr i Kina i 1949 viste tydeligt, at national vækkelse (krigen mod japanerne) og social revolution (først og fremmest løftet om jordreform) tilsammen udgjorde et effektivt 
grundlag for at mobilisere store dele af befolkningen. Måske var det Liangs fastfrysning af magtforholdene, der gjorde det umuligt at skabe den spontaneitet og vilje til selvorganisering, som han egentlig $\emptyset$ nskede at udvikle. I modsætning til højskolerne blev landsbyskolerne ved med at være udtryk for at nogen (staten, de intellektuelle, byboerne) trængte ind i bøndernes verden og ændrede deres livsformer uden samtidig at give dem øget indflydelse på deres eget liv.

Noter:

1 Disse første reformer er fx beskrevet i Knight Biggerstaff: The Earliest Modern Government Schools in China, Itaca, New York: Cornell University Press, 1961; Paul J. Bailey: Reform the People. Changing attitudes towards popular education in early twentieth-century China, Edinburgh: Edinburgh University Press, 1990; Sally Borthwick: Education and Social Change in China. The Beginnings of the Modern Era, Stanford, Cal.: Hoover Institution Press, 1983.

2 Cai Wensen: »Danmai zhi buxi jiaoyu« [Efteruddannelse i Danmark], Jiaoyu zazhi [Uddannelse] vol. 2, nr. 3, 1909, pp. 21-25.

3 Guo Yao: »You Danmai zaji « [Noter fra en Danmarkstur], Xin qingnian [Ny Ungdom], vol. 6, no. 1, 1919, pp. 62-64.

4 Udenlandsk indflydelse på kinesisk uddannelse diskuteres i en række artikler i Ruth Hayhoe and Marianne Bastid (eds.): China's Education and the Industrialized World, Armonk, New York, London: M.E. Sharpe, 1987.

5 Jing Yu: »Danmai zhi pingmin zhongxuexiao« [Danmarks folkemellemskoler], Jiaoyu zazhi, vol. 6, no. 3, 1914, pp. 21-25.

6 Se fx Ren Baitao: »Ou-Mei zhi buxi jiaoyu« [Efteruddannelse i Europa og Amerika], Jiaoyu zazhi, vol. 16, no. 11, 1924.

7 Ren Baitao: »Ou-Mei chengren jiaoyu zhi boxing « [Opblomstringen af voksenundervisning i Europa og Amerika], Jiaoyu zazhi, vol. 16, no. 12, 1924. 
8 Chen Duxiu: »Jindai Xiyang jiaoyu« [Moderne vestlig uddannelse], Xin qingnian, vol. 3, no. 5, 1917.

9 En interessant analyse af denne bølge og en af dens hovedfigurer kan findes i Charles W. Hayford: To The People. James Yen and Village China, New York: Columbia University Press, 1990.

Mao Tsetung: Udvalgte skrifter, København: Demos, 1974, pp. 17-27.

1 Se fx Wu Zengjie: »Zuijin Danmai zhi nongcun jiaoyu« [Landsbyuddannelse i Danmark i den seneste tid], Jiaoyu zazhi, vol. 20, no. 9, 1928; Sun Zerang: »Danmai zhi heping geming« [Danmarks fredelige revolution], Cunzhi [Landsbystyre], vol. 1, no. 9, 1929; Bao Youshen: »Nongcun hezuo yundong wenti« [Spørgsmålet om kooperativbevægelsen i landsbyerne], Cunzhi, vol. 1, no. 11, 1930.

J.B. Tayler: »Danmai yu Zhongguo xiangcun gaijian wenti « [Danmark og spørgsmålet om omformningen af Kinas landområder], Dongfang zazhi [Østen], vol. 25, no. 23, 1928.

Zheng Guanzhao: »Danmai de chengren jiaoyu« [Voksenundervisning i Danmark], Jiaoyu zazhi, vol. 20, no. 10, 1928.

Zhu Ranli: »Danmai de nongcun jianshe yu Danmai de nongcun jiaoyu« [Anmeldelse af den kinesiske oversættelse af Harold W. Foght: Rural Denmark and its Schools], Jiaoyu zazhi, vol. 20, no. 11, 1928.

Lei's rigtige navn var Lei Peihong (f. 1888), og han var blandt vesterlændinge kendt som Binnan P. Louis. Han spillede en hovedrolle i udviklingen af et moderne uddannelsessystem i Guangxi før 1949. Fra 1949 frem til sin død i 1967 indtog han en række formelt høje men ikke specielt indflydelsesrige politiske poster i samme provins. Hans Grundtvig-biografi havde titlen »Bei-Ou de xianjuezhe Gelongwei« [Grundtvig, Nordens profet], Jiaoyu zazhi, vol. 20, no. 9, 1928. Lei skrev senere en tilsvarende biografisk artikel om Christen Kold: „Bei-Ou chengren jiaoyuzhe Kele« [Nordens voksenunderviser: Kold], Jiaoyu zazhi, vol. 23, no. 8, 1931. Han præsenterede også dansk jordlovgivning (Dongfang zazhi, vol. 25, no. 21, 1928), andelsbevægelsen (Dongfang zazhi, vol. 26, no. 2, 1929) og folkebibliotekerne (Jiaoyu zazhi, vol. 21, no. 7, 1929). Helt frem til 1947 findes Danmark og Grundtvig hyppigt omtalt i hans skrifter: Lei Peihong wenji [Lei Peihongs samlede skrifter], vol. 1 og 2, Nanning: Guangxi jiaoyu chubanshe, 1989 og 1990. 
De følgende fire afsnit er en omarbejdet version af min artikel »Liang Shuming and the Danish Model i Søren Clausen, Roy Starrs, and Anne Wedell-Wedellsborg (eds.): Cultural Encounters: China, Japan and the West, Århus: Aarhus University Press, 1995, pp. 267-288.

17 For en fremragende biografi over Liang, der dog overraskende ikke nævner hans inspiration fra Danmark, se Guy S. Alitto: The Last Confucian. Liang Shu-ming and the Chinese Dilemma of Modernity, Berkeley, Los Angeles, London: University of California Press, 2. ed., 1986.

Liang Shuming: »Danmai de jiaoyu yu women de jiaoyu « [Dansk uddannelse og vores uddannelse], (1931) Liang Shuming quanji [Liang Shumings samlede værker] vol. 7, Jinan: Shandong renmin chubanshe, 1993, pp. 653-84.

19 Liang Shuming: »Dong-Xi ren de jiaoyu zhi bu tong « [Forskelle på østlig og vestlig uddannelse], Liang Shuming quanji, vol. 4, pp. 655-59.

20 Liang Shuming: »Dui Dong-sheng shijian zhi ganyan« [Et udtryk for mine følelser omkring hændelsen i de østlige provinser] (1931), Liang Shuming quanji, vol. 5, pp. 295-300.

21 Liang Shuming: »Jingshen taolian yaozhi« [Essensen af åndelig træning] (1934), Liang Shuming quanji, vol. 5, pp. 429-519.

22 Oplysningerne om Manniches rejse i 1934 stammer fra en kopi af hans rapport til Udenrigsministeriet dateret 5.10.1934 opbevaret i Peter Manniches privatarkiv i Rigsarkivet.

23 Liang Shuming: "Yu Danmai de liang jiaoshou de tanhua« [En samtale med to danske professorer] (1934), Liang Shuming quanji, vol. 5, pp. 571-76.

24 Fra et upubliceret manuskript opbevaret i Peter Manniches privatarkiv i Rigsarkivet.

25 Se Alitto op.cit. pp. 238-78 for en nærmere beskrivelse.

26 Det følgende bygger primært på Song Leyan: »Zouping de chengnian jiaoyu« [Voksenundervisning i Zouping], part 1, Xiangcun jianshe [Genopbygning af Landområderne], vol. 6, no. 15, 1937 og part 2, ibid., no. 16. 
ibid., part 2.

28 Liang Shuming: »Women de liang da nanchu « [Vores to store vanskeligheder] (1936), Liang Shuming quanji, vol. 2, pp. 573-85.

${ }^{29}$ Mao Zhongyin og Chang Xiaochun (eds.): $Y u$ Qingtang jiaoyu lunzhu xuan [Udvalgte uddannelsesskrifter af Yu Qingtang], Beijing: Renmin chubanshe, 1992, pp. 173-74, 178-80, 276-77, 300. 